\title{
Comparative lifecycle assessment of alternatives for waste management in Rio de Janeiro - Investigating the influence of an attributional or consequential approach
}

\author{
A. Bernstad Saraiva ${ }^{a, *}$, R.G. Souza ${ }^{\text {b }}$, R.A.B. Valle ${ }^{a}$ \\ ${ }^{a}$ SAGE/COPPE, UFRJ, Rio de Janeiro, Brazil \\ ${ }^{\mathrm{b}}$ Institute of Science and Technology, UNESP - Univ Estadual Paulista, São José dos Campos, Brazil
}

\section{A R T I C L E I N F O}

\section{Article history:}

Received 1 November 2016

Revised 12 June 2017

Accepted 2 July 2017

Available online 13 July 2017

\section{Keywords:}

Lifecycle assessment

Solid waste management

Municipal solid waste

CLCA

Consequential

\begin{abstract}
A B S T R A C T
The environmental impacts from three management alternatives for organic fraction of municipal solid waste were compared using lifecycle assessment methodology. The alternatives (sanitary landfill, selective collection of organic waste for anaerobic digestion and anaerobic digestion after post-separation of organic waste) were modelled applying an attributional as well as consequential approach, in parallel with the aim of identifying if and how these approaches can affect results and conclusions. The marginal processes identified in the consequential modelling were in general associated with higher environmental impacts than average processes modelled with an attributional approach. As all investigated waste management alternatives result in net-substitution of energy and in some cases also materials, the consequential modelling resulted in lower absolute environmental impacts in five of the seven environmental impact categories assessed in the study. In three of these, the chosen modelling approach can alter the hierarchy between compared waste management alternatives. This indicates a risk of underestimating potential benefits from efficient energy recovery from waste when applying attributional modelling in contexts in which electricity provision historically has been dominated by technologies presenting rather low environmental impacts, but where projections point at increasing impacts from electricity provision in coming years. Thus, in the present case study, the chosen approach affects both absolute and relative results from the comparison. However, results were largely related to the processes identified as affected by investigated changes, and not merely the chosen modelling approach. The processes actually affected by future choices between different waste management alternatives are intrinsically uncertain. The study demonstrates the benefits of applying different assumptions regarding the processes affected by investigated choices - both for provision of energy and materials substituted by waste management processes in consequential LCA modelling, in order to present outcomes that are relevant as decision support within the waste management sector.
\end{abstract}

(c) 2017 Elsevier Ltd. All rights reserved.

\section{Introduction}

Environmentally sound municipal solid waste (MSW) is a worldwide concern, but of particular priority in transition countries with large urban areas, dense populations and challenging geographical conditions. The per capita waste generation in countries like Brazil still is low (1.041 kg/capita and day in 2013) (Abrelpe, 2014), compared to Sweden and the US (1.263 and $1.995 \mathrm{~kg} /$ capita and day in 2013 respectively) (Waste Sweden, 2014; EPA, 2015). However, the total generation of MSW in Brazil in 2013 was estimated to almost 210,000 tons per day, an increase

\footnotetext{
* Corresponding author.

E-mail address: anna.bernstad.saraiva@sage.coppe.ufrj.br (A. Bernstad Saraiva).
}

by $4.1 \%$ compared to the year before, while population increased by $3.7 \%$ (Abrelpe, 2014). Although waste management in Brazil is focused primarily on eliminating waste disposal in open dumps, the newly implemented National Solid Waste Policy, (PNRS, 2010) opens the possibilities for technological leapfrogging and introduction of more advanced waste-to-energy and material recovery technologies, not necessary leading to disposal in sanitary landfills. The environmental benefits of such strategies could be investigated through use of lifecycle assessment (LCA) methodology.

According to Laurent et al. (2013), there is an evident confusion of concepts and terminology surrounding different types of Lifecycle Inventory (LCI) modelling frameworks in previous LCAs of solid waste systems. One of the reasons identified behind this is a lack of 
adequate goal definition, and subsequently, lacking stringency in the choice of LCI modelling framework. The selected type of LCI modelling framework has a significant influence on the definition of system boundaries (EC, 2010). Attributional lifecycle assessment (ALCA) employs a system-modelling approach in which the inputs and outputs are attributed to the functional unit of a product system by linking and/or partitioning the unit processes of the system according to a normative rule (Sonnemann and Vigon, 2011). Consequential LCA (CLCA), on the other hand, is change-oriented and quantifies the effects associated with changes in the life cycle of a system brought about by a decision (Curran et al., 2005). In this way, the consequential approach seeks to take the environmental assessment a step further, in order to analyse how environmental burdens may vary in response to changes when processes are linked via market mechanisms beyond the foreground system (Vázquez-Rowe et al., 2013). Such linkages occur for example when waste is used for energy or material recovery, as wastebased goods are released on the market, with the effect of substituting other product-systems.

Several studies have been performed in recent years, using a consequential framework for LCI modelling of waste management systems. Boesch et al. (2014) compared an attributional and a consequential modelling of a Swiss MSW management scenario, considering substitution of both fossil and renewable energy to improve consequential LCI (CLCI) modelling, referring to recommendations by Mathiesen et al. (2009). No considerations were taken to affected suppliers in the modelling of material recovery, and average data was used for these processes in the study. Sevigné-Itoiz et al. (2015) present a CLCA of different alternatives for end-of-life treatment of plastic waste. The identification of marginal electricity was based on projections from national governments and the IEA. Assumptions of substituted heat were not justified and average data was used for modelling of production of virgin plastic substituted through material recycling. Comparing ALCA and CLCA modelling of end-of-life treatment of construction materials, Sandin et al. (2014) refer to literature data in identifying marginal heat provision processes, while data representing current average technologies is used for modelling of substituted materials. The influence of technology development was evaluated through 'explorative' scenarios, investigating the possible range of future outcomes by assuming a single technology to be representative for average future technology. Tonini and Astrup (2012) chose to investigate both short- and long-term changes related to the introduction of a waste refinery system, using CLCI modelling. Average processes were used in the modelling of virgin production of metals, plastics and glass as well as inorganic fertilizers substituted by recycled waste materials and organic fertilizers respectively. Cimpan et al. (2015) consider substitution of both energy and virgin material in a CLCA of a Danish waste management system. While the affected suppliers of virgin metals, plastics and glass not could be identified, marginal nitrogen, phosphorus and potassium fertilizers were identified as calcium ammonium nitrate, diammonium phosphate and potassium chloride, based on Hamelin (2013). In a review of Danish and Swedish consequential LCAs of waste management systems, Mathiesen et al. (2009) demonstrated the wide application of the methodology suggested by Ekvall and Weidema (2004) for identification of affected electricity provision. However, the same authors also stated that reviewed studies did not apply the suggested methodology consistently, and that the current practice should be improved by 1) using combined affected technologies, i.e. a complex set of marginal technologies; 2) using long-term perspectives by identifying affected technologies in several possible future scenarios, and 3) identifying the affected technologies based on energy system analysis with realistic geographical distributions and distribution in time.
The aim of the present paper was to investigate different waste management alternatives under two different LCI-modelling approaches. The objective to discussed if and why different treatment alternatives come across as more beneficial than others, depending on the chosen approach, and how this can affect input given to decision makers. In the present study, the environmental performances of three different scenarios for future development of the municipal solid waste management (MSWM) system in the city of Rio de Janeiro are assessed with an attributional as well as a consequential LCI-modelling approach. The functional unit is set to the collection and treatment of 1 ton of domestic waste, as collected by the municipal waste collection agent.

Energy provision is the background system of principal relevance to the system studied in the present study. MSW management is also increasingly integrated with material provision systems through material recovery and recycling, where environmental benefits can arise through avoidance of virgin material provision. Once a process avoided by waste-to-energy and material recycling or recovery is identified, the affected technology, also referred as marginal (Weidema et al., 2009), should be identified. This is commonly a key issue in consequential LCA modelling. A specific objective is therefore also to compare two different approaches for identification of the processes and technologies affected by the changes investigated in the consequential assessment of environmental impacts.

\section{Methodology}

Two different approaches were applied for identification of processes and technologies affected by the changes investigated in the present study. Firstly, the methodology suggested by Weidema et al. (2009) is used in a consistent manner for identification of single marginal technologies for production of electricity. This analysis is compared with the official national energy balance plan. Affected technologies and processes related to the handling of biofertilizers from waste management were identified through the approach presented by Weidema et al. (2009), using two different approaches for market delimitation. In the attributional modelling, average data was used for modelling of electricity and fertilizer production. As system enlargement was applied also in the attributional modelling, and factors such as rebound effects were not addressed in the consequential modelling, the largest difference between the two approaches lies within the identification of the unit processes linked to each system.

\subsection{Scenario description}

The selected functional unit is $1000 \mathrm{~kg}$ of mixed municipal solid waste, with the composition presented by the local government (COMLURB, 2014). The fraction of organics in domestic waste in the city of Rio de Janeiro has decreased from 60.7 to $52.8 \%$ over the period 2005-2013. However, over the same period, the amount of domestic waste increased by $25 \%$, resulting in an overall increase of domestic organic waste by $8.5 \%$ (COMLURB, 2014). Thus, handling of this fraction is of large importance, and was also selected to be the focus of the present study. The scenarios investigated in the study are presented in Table 1.

\subsection{LCA study methodology}

Exclusively covering the MSW end-of-life phase, this LCA study was conducted following the international standards ISO 14040 and 14044 (ISO, 2006a and b). All scenarios were modelled in the EASETECH software, developed by DTU. This software is based on material flow modelling and enables generation of input- and 
Table 1

Scenarios compared in the present study.

\begin{tabular}{|c|c|}
\hline Scenario & Description \\
\hline S1 & $\begin{array}{l}0 \% \text { separate collection of organics. Landfilling of all MSW with } \\
\text { collection of landfill gas and combustion of the same for } \\
\text { generation of electricity (current situation) }\end{array}$ \\
\hline S2 & $\begin{array}{l}\text { Separate collection of } 50 \% \text { organics for anaerobic digestion. } \\
\text { Combustion of generated biogas in engine generating electricity. } \\
\text { Landfilling of residual waste (including non-separated organics). } \\
\text { Collection and combustion of landfill gas for generation of } \\
\text { electricity. Use of digestate as fertilizer on farmland }\end{array}$ \\
\hline S3 & $\begin{array}{l}\text { Common collection of all MSW and post-separation of organics } \\
\text { ( } 75 \% \text { of total) in material recover facility (MRF). Anaerobic } \\
\text { digestion of mechanically separated organic waste. Combustion of } \\
\text { generated biogas in engine generating electricity. Landfilling of } \\
\text { residual waste and of digestate produced in AD. Collection and } \\
\text { combustion of landfill gas for generation of electricity }\end{array}$ \\
\hline
\end{tabular}

process-specific results. Lifecycle impact assessment (LCIA) categories and methods recommended by ILCD (2011) were used. These categories were: Climate change (as Global Warming Potential, GWP), Ozone Depletion Potential (ODP), Particulate matter (PM), Photochemical Oxidant Formation (POF), Eutrophication marine (EU-marine), Acidification, Human Toxicity cancer effects (HT-carc and non-carc). Due to problems of importing some ecoinvent v3 datasets to the EASETECH software, modelling of production of fertilizers was made in Simapro. LCIA methods used in these two softwares were compatible in all cases, exempt for ecotoxicity. This impact category was therefore excluded from the assessment.

\subsection{Lifecycle inventory data}

Current and potential future systems for MSW management in Rio de Janeiro city were modelled, including collection, pretreatment (when relevant), final treatment and further handling of by-products/secondary waste. The composition of domestic waste was based on official statistics, presented by COMLURB (2014). According to this data, the fraction of biowaste, plastic, paper and metal waste reached 52.8, 19.0, 16.8 and $1.6 \%$ respectively in 2013. The fraction of other combustible waste (leather, wood, textiles, etc.) and inserts reached $4.9 \%$ and $4.5 \%$ respectively the same year (COMLURB, 2014). The relation between animal and vegetable food waste was set to 12 and $88 \%$ respectively based on Bernstad and Andersson (2015). Characteristics of waste fractions were based on Riber et al. (2009). Diesel use in collection and transport to the treatment site was assumed to $1.30 \mathrm{~L} / \mathrm{t}$ wet waste (ww) (Angelo et al., 2017). The same amount of diesel per ton ww was assumed in all scenarios, as two-compartment trucks, simultaneously collecting organic waste and residual waste, assumedly would perform source-separation. Data used in the modelling of waste handling is presented in Tables 2 and 3.

Table 2

Parameters used in modelling of landfill and anaerobic digestion. LFG = Landfill gas

\begin{tabular}{|c|c|c|c|}
\hline Parameter & Value & Unit & Reference \\
\hline \multicolumn{4}{|l|}{ Landfill } \\
\hline Years of utility & 18 & Years & Abrelpe (2012) \\
\hline Leachate collection (year $1-30$ ) & 90 & $\%$ & Assumed \\
\hline Leachate collection (year 31-100) & 50 & $\%$ & Assumed \\
\hline Methane oxidation in top cover & 10 & $\%$ & Assumed \\
\hline Density & 1 & $\mathrm{t} / \mathrm{m}^{3}$ & Assumed \\
\hline Height & 50 & $\mathrm{M}$ & Abrelpe (2012) \\
\hline Diesel use (operation) & 0.003 & $\mathrm{~kg} / \mathrm{t}$ waste & da Silva (2011) \\
\hline Diesel use (construction) & $3.4 \mathrm{E}-06$ & $\mathrm{~kg} / \mathrm{t}$ waste & da Silva (2011) \\
\hline Concrete (construction) & 0.00011 & $\mathrm{~kg} / \mathrm{t}$ waste & da Silva (2011) \\
\hline High density polyethylene (HDPE) (construction) & 0.003 & $\mathrm{~kg} / \mathrm{t}$ waste & da Silva (2011) \\
\hline Gas collection (year $1-50$ ) & 50 & $\%$ & Abrelpe (2012) \\
\hline Gas collection (year 51-100) & 0 & $\%$ & Abrelpe (2012) \\
\hline Flaring of collected LFG & 40 & $\%$ & Abrelpe (2012) \\
\hline Use of electricity in leachate treatment & 0.443 & $\mathrm{~kW}$ h/t waste & Yoshida et al. (2014) \\
\hline Electricity recovery (LFG) & 36 & $\%$ & Genrup and Jonshagen (2011) \\
\hline \multicolumn{4}{|l|}{ Anaerobic digestion } \\
\hline Electricity use in pre-treatment & 12.6 & $\mathrm{kWh} / \mathrm{t}$ ww & Waste Management Sweden (2013) \\
\hline Electricity use in dry AD & 14 & $\mathrm{~kW} \mathrm{h/t} \mathrm{ww}$ & DWMT (2014) \\
\hline Methane emissions in dry AD & $0.5 \%$ & $\%$ of $\mathrm{CH}_{4}$ & DWMT (2014) \\
\hline DS in digestate (prior to dewatering) & 35 & $\%$ & DWMT (2014) \\
\hline Electricity use in dewatering (digestate) & 35 & $\mathrm{kWh} / \mathrm{t}$ ww & Balmér (2012) \\
\hline DS in digestate (post dewatering) & 60 & $\%$ & Balmér (2012) \\
\hline Transport of digestate & 0.007 & L diesel $/ \mathrm{km}, \mathrm{t}$ & Angelo et al. (2017) \\
\hline Electricity recovery (biogas) & 36 & $\%$ & Genrup and Jonshagen (2011) \\
\hline
\end{tabular}

Table 3

Nutrient content in generated digestate and parameters used in modelling of on-land application.

\begin{tabular}{|c|c|c|c|}
\hline Parameter & Value & Unit & Reference \\
\hline $\mathrm{N}_{2} \mathrm{O}-\mathrm{N}$ emissions (direct) ${ }^{\mathrm{a}}$ & 1.25 & $\%$ of $\mathrm{N}$-tot & IPCC (2006) \\
\hline $\mathrm{NH}_{3}-\mathrm{N}$ emissions ${ }^{\mathrm{a}}$ & 15 & $\%$ of $\mathrm{N}$-tot & OSB/WSTB (2000) \\
\hline $\mathrm{NO}_{3}^{-}-\mathrm{N}$ emissions ${ }^{\mathrm{a}}$ & 20 & $\%$ of $\mathrm{N}$-tot & OSB/WSTB (2000) \\
\hline Incoming $\mathrm{N}$ content $\mathrm{t}^{\mathrm{b}}$ & 4.85 & $\mathrm{~kg} \mathrm{~N}$-tot/ton ww & Based on modelling \\
\hline Incoming $\mathrm{P}$ content $\mathrm{b}^{\mathrm{b}}$ & 0.65 & kg P-tot/ton ww & Based on modelling \\
\hline Incoming $\mathrm{K}$ content $\mathrm{t}^{\mathrm{b}}$ & 1.48 & kg K-tot/ton ww & Based on modelling \\
\hline Application of digestate & 20 & $\mathrm{MJ} / \mathrm{t}$ digestate & Borgshed et al. (2003) \\
\hline Application of mineral fertilizers & 0.36 & $\mathrm{MJ} / \mathrm{kg} \mathrm{N}$-tot & Finnveden et al. (2000) \\
\hline
\end{tabular}

a Digestate and mineral fertilizers on farmland.

b In food waste only, as $\mathrm{kg}$ per ton mixed incoming waste. 
Carbon storage in landfill as well as in soil after application of digestate on farmland (in scenario 3), was assumed to zero in the based case of the present study. According to Smith et al. (2001), the sequestration potential is strongly dependent on the type of organic material (i.e. the amount of resistant organic matter such as lignin) and climate (i.e. increases in cold climates, and decreases in warm and moist climates). The fraction of biodegradable carbon in food waste which is not mineralized over the investigated timeframe (in this case limited to 100 -years) was estimated to $11 \%$ by Smith et al. (2001), representative for northern European conditions. However, as these estimations are made for conditions very different to the ones in tropical moist areas, carbon sequestration was excluded in the base case of the study. The potential influence of considering carbon sequestration from landfills as well as from digestate spread on farm land was however investigated in a sensitivity analysis.

In the attributional approach, national and global averages, based on historical data were used. Electricity provision was modelled as the average Brazilian electricity mix (based the process for medium voltage electricity from grid in ecoinvent 3.0. For details, see Table 1 SI. However, emissions of GHG were adjusted to represent official statistics of the GHG-emissions from the national electricity system over the period 2010-2014, based on national statistics, resulting in $0.07547 \mathrm{t} \mathrm{CO}_{2}$-eq/MW $\mathrm{h}$ (MME, 2015). This process is referred to as "average mix" in the following. Global average data for fertilizer provision (Nitrogen fertilizer (as $\mathrm{N}$ ), Phosphate fertilizer (as $\mathrm{P}_{2} \mathrm{O}_{5}$ ) and Potassium (as $\mathrm{K}_{2} \mathrm{O}$ ), from the ecoinvent 3.0), were also applied.

For the consequential modelling of the system, identification of marginal processes was made based on two different approaches, explained in detail in the below.

\subsection{Identification and modelling of affected processes}

Laurent et al. (2013) presented a guidance to facilitate identification of the most adequate LCI-modelling framework in a specific situation. According to the guidance, LCAs generated as basis for decision-making should be modelled as a mix of long-term marginal processes when large-scale consequences on the background system can be expected. In a Brazilian perspective, waste-toenergy is still rare. However, recent changes in the national waste management legislation firmly point at the necessity of increasing the disposal of solid waste in sanitary landfills with energy recovery, as well as source-segregating organic waste in order to achieve recovery of nutrients (IPEA, 2014). In Brazil, with a generation of almost 210,000 tons of MSW per day (Abrelpe, 2014), changes in the current management could imply large-scale consequences on background systems in the local/regional context. Due to the lack of transfer-capacity.

2.4.1. Affected technologies for Brazilian electricity provision identification based on method presented by Weidema et al. (2009)

According to the methodology suggested by Weidema et al. (2009), the procedure for identification of which unit processes to link, has four steps:

\section{- Identifying the scale and time horizon of the potential change studied \\ - Identifying the limits of a market \\ - Identifying trends in the volume of a market \\ - Identifying changes in supply and demand}

Detailed information about how these steps were handled is presented in the SI, while a summary is presented in the below.

The changes investigated in the present study are considered small (marginal) in a national context, implying that it does not affect the determining parameters of the overall market situation, and studied changes are assumed to be long-term, with potential installation of new capacity. According to national statistics (ONS, 2015), the electricity demand in Brazil has increased by more than $20 \%$ over the period 2009-2015. National projections point at a continuing increase in electricity demand (PNE, 2014). As the majority of the Brazilian biomass fueled power plants are dependent on waste material from the sugarcane industry, the expansion of bioenergy is constrained by developments in sugar and ethanol demand. Lack of investments in transmission capacity from north to south could constrain both hydro and wind power installations. There are plans of new transmission capacity, to be taken into use from the second part of 2021 (ONS, 2015). However, even if these plans are realized, they are insufficient in relation to the needs. The government projects a necessary increase in generation capacity placed in the south/southeastern parts of the country (PDE, 2014). This capacity must be ready to be started and generate electricity within a few hours after notice (PDE, 2014).

Results from the latest national electricity auctions show that large hydropower followed by wind power are the most competitive suppliers, delivering at 155 and $179 \mathrm{BRL} / \mathrm{MWh}$ respectively (EPE, 2015). However, due to constraints presented above, it was assumed that the single marginal technology must be flexible in terms of location and operation. Several potentially relevant fuels (coal, oil derivates and natural gas) can be found within the Brazilian territory. However, the majority of the Brazilian coal reserve has low quality, with high content of ash and sulfur, and low energy content (ANEEL, 2009). Vast increase in diesel use is limited by the lack of national refinery capacity. Important reserves of natural gas have been confirmed on Brazilian territory. In December 2014 , the national production of natural gas reached $98.15 \mathrm{Mm}^{3} /$ day (ANP, 2015), an increase of the internal production by $7-10 \%$ from 2012 to 2014, while the national consumption increased by $22 \%$ in 2014 (ANP, 2015). The import of natural gas from Bolivia, with a capacity of $30 \mathrm{Mm}^{3}$ /day is therefore vital for the Brazilian market and prolonged and potentially increased transfer capacities are discussed (Portal Brasil, 2014). The last years have demonstrated a political will to decrease the dependency of the import of natural gas from Bolivia, resulting in investments in import of liquid natural gas (LNG) to the southeastern parts of the country. This was first seen as a temporary measure in the light of the draught in 2012, resulting in reduced hydropower generation, but renewed import licenses has increased the possibilities of this import becoming a stabile input to the Brazilian electricity matrix. The major part (over 75\%) of imported LNG in 2012 originated from Quatar, Nigeria and Trinidade and Tobago and the end use is primarily generation of electricity (ANP, 2015). The cost for this electricity is thereby high, making it likely that new construction of generation capacity would decrease the demand, and at the current, natural gas appears to be the most likely fuel for marginal electricity production, seen in a mid-term perspective.

\subsubsection{Affected technologies for Brazilian electricity provision - identification based on national plans and projections}

In 2014, the Brazilian government presented a ten-year plan for national energy expansion (EPE/MME, 2014). The plan is built on expectations of a yearly GDP growth of $3.2 \%$ and a population increase of $0.7 \%$ per year. The structure of the national economy is expected to be the same as in the year 2014, i.e. dominated by services (67.1\%), followed by industry (27.3\%) and animal agriculture (5.5\%). An increased demand of electricity is assumed to increase the installed electricity production capacity by $56 \%$ between the years 2015 and 2024, equal to 74,600 MW over the same period. The largest increase is assumed to take place in the northern part of the country. Based on given permits and existing plans for installation of new generation capacity, a profile of the 


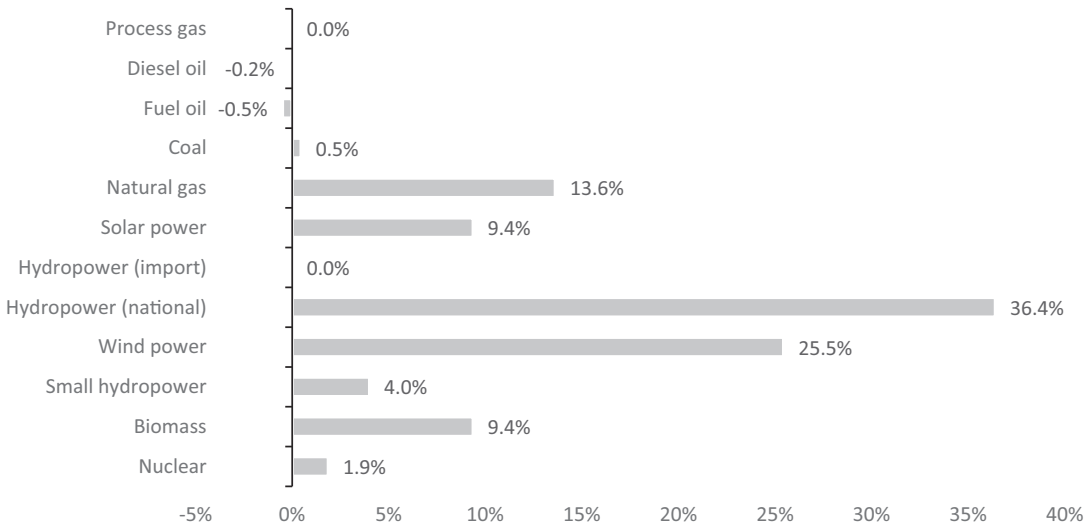

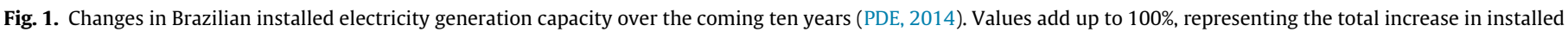
capacity (74,600 MW) over the period 2015-2024.

changes in electricity generation capacity over the coming ten years could be established (Fig. 1).

\subsubsection{Affected technologies for production of fertilizers}

Brazil consumes around 32.2 Mt of mineral fertilizers each year (ANDA, 2015). In 2014, the use of nitrogen, phosphorus and potassium fertilizers increased by $4.7 \%, 2.4 \%$, and $5.9 \%$ respectively (ANDA, 2015). Only around $30 \%$ of the demand is produced internally, and several national strategies have been developed to decrease the country's dependency on imports. An increasing demand has been followed by increasing prices. The national costs for import of fertilizers to Brazil hit a new record in 2015 (ANDA, 2015).

Due to the rather low concentration of nutrients in digestate from organic MSW, the transport distance must be kept to a minimum. It would thereby not be relevant to assume application of digestate on crops not cultivated in the absolute proximity of the anaerobic digestion plant. Thus, in order to identify the types of fertilizers affected by the generation of digestate in the casestudy area, the dominating crops in the region were identified as tomato, mandioc and banana (IBGE, 2013).

An assessment of the types of fertilizers commonly used for these crops shows that urea is the most relevant choice of marginal mineral nitrogen fertilizer. Amongst potassium fertilizers, previous studies have shown that potassium chloride is the dominant product, covering 98\% of the Brazilian demand (FAO, 2002). In the case of phosphate fertilizers, simple superphosphate was the only phosphate fertilizer used in both mandioc and banana production, and thus, assumed to be the marginal one. In the modelling of marginal fertilizers, adjustment of average global datasets were made to represent Brazilian marginal conditions in terms of electricity use in the fertilizer production chain, using the two approaches for identification of marginal electricity production presented above.

Substitution of composted green waste by produced digestate was assessed in parallel to the substitution of marginal mineral fertilizers. Emissions from low-tech composting of organic waste and application of the same on farmland would in this case be avoided. If no alternative use is found for the waste previously composted, it is likely that this will degrade naturally, partly anaerobically, or be subject to open-air burning. Emissions from open-air burning of vegetation were gathered from Yokelson et al. (2008), and emissions from composting were based on default values presented by IPCC (2006) in the case of $\mathrm{CH}_{4}$ and $\mathrm{N}_{2} \mathrm{O}$, and Shen et al. (2011) in the case of $\mathrm{NH}_{3}$. Emissions from on-land application of digestate and compost were assumed to be the same as in the case of digestate, based on Nordic Council of Minister (2007). Substitution of compost was made on nutrient content basis, assuming nitrogen as the determining macronutrient, using average data presented by Andersen et al. (2011) for nitrogen content in compost. This resulted in a substitution ratio of 1.73 tons of green waste per ton organic waste treated by anaerobic digestion.

\section{Results}

The two methods used for identification of marginal electricity production generated results with largely different environmental impacts (Fig. 2). While emissions related to GWP, OD, POF, A and E (marine) are higher from electricity based on combustion of natural gas in power plants, the complex marginal mix assessed through official projections generate higher impacts in terms of HT (canc. and non-canc.) and PM. Impacts to HT and PM are primarily related to combustion of biomass.

The emission profiles from electricity production presented above were applied in modelling of the three waste treatment scenarios presented in Table 1, resulting in the impacts presented in Fig. 3 (assuming that production of mineral fertilizers are affected by production of digestate) and 4 (assuming that composting is affected by production of digestate). Results are presented in relation to each of the three waste treatment scenarios (S1 (current situation), S2 (source-segregation of $50 \%$ of organics for biogas) and S3 (post-sorting of organics for biogas)) under three different assumptions for electricity provision (current average - used in attributional modelling, combustion of natural gas - used in consequential modelling ( $\mathrm{C} 1$ ), and marginal mix based on the national energy plan - used in consequential modelling (C2)).

Results show that scenario 3 (anaerobic digestion of organic waste after post-separation) is the preferable alternative in relation to most of the included impact categories when using the attributional approach as well as the consequential approach, assuming that digestate will substitute mineral fertilizers. However, when assuming that digestate will substitute green compost and that natural gas is the affected technology for electricity provision, scenario 2 is preferable in relation to the largest number of impact categories. The performances in each impact category can be explained as following:

GWP - Unrecovered methane from landfills dominate emissions, and thus, emissions increase with increasing amount of landfilled organic waste, while substitution of electricity and fertilizers reduce emissions, making S2 the preferred scenario when applying a consequential modelling, as the benefits from substitution of marginal fertilizers are higher in case, while S3 is the preferred alternative when attributional modelling is applied (Fig. 3). Assuming that composting is substituted by digestated produced in S2 result in lower avoidance of GWP compared to 


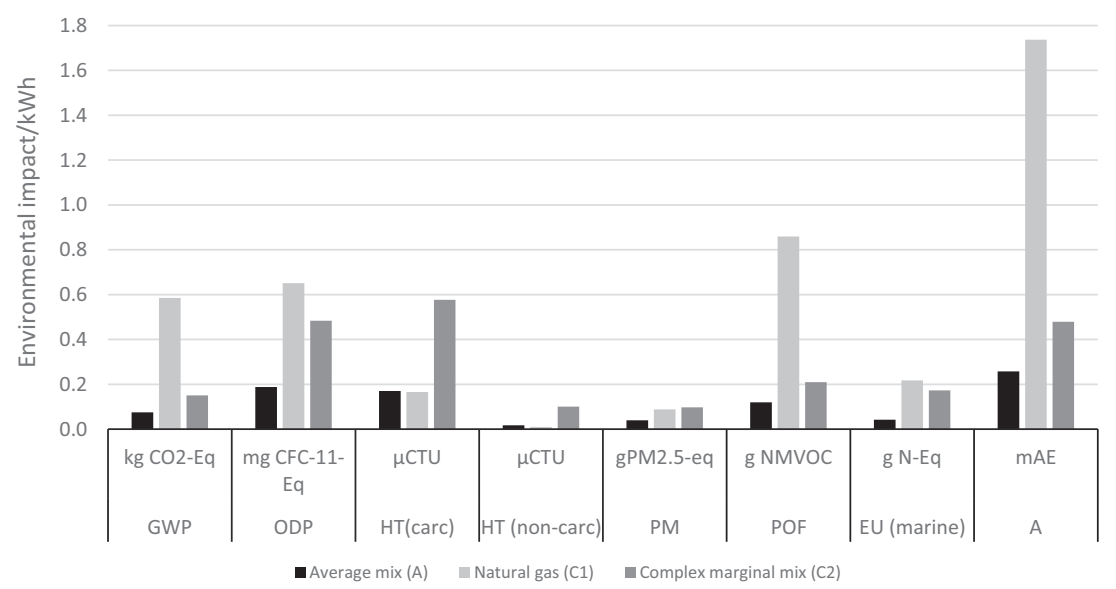

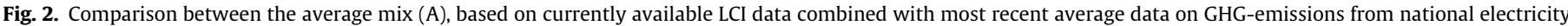
generation, and the modelling of the two marginal electricity generation capacities identified in the study (C1 and $\mathrm{C} 2$ ).

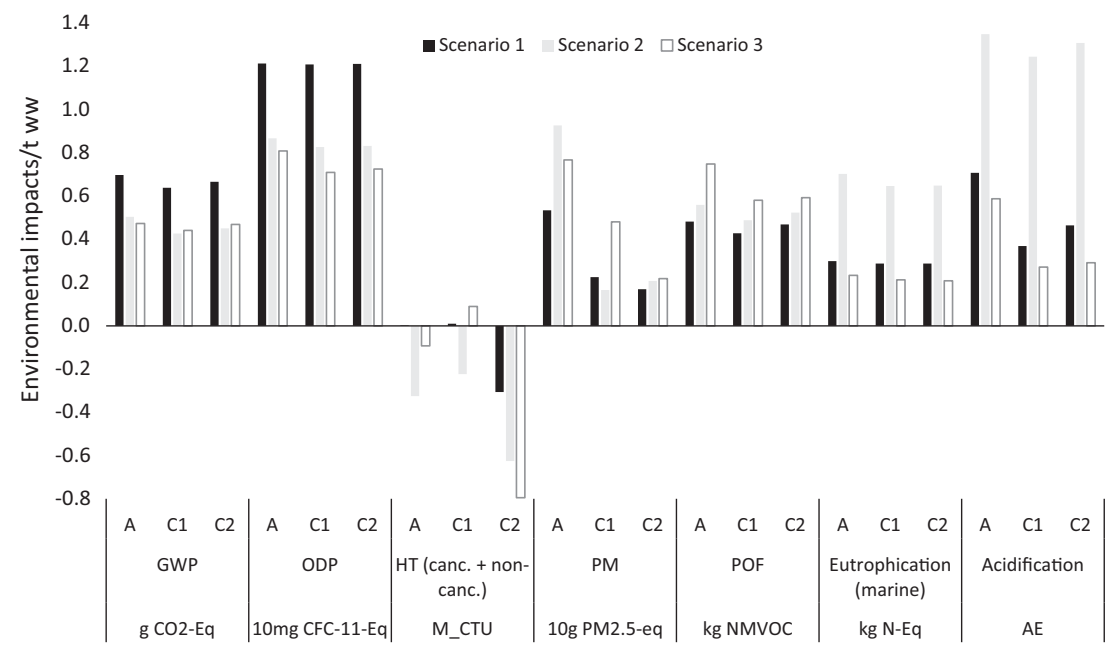

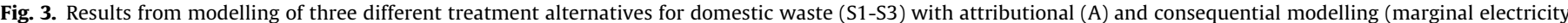

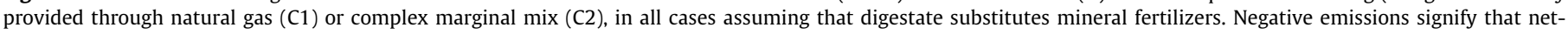
emissions from scenarios are negative.

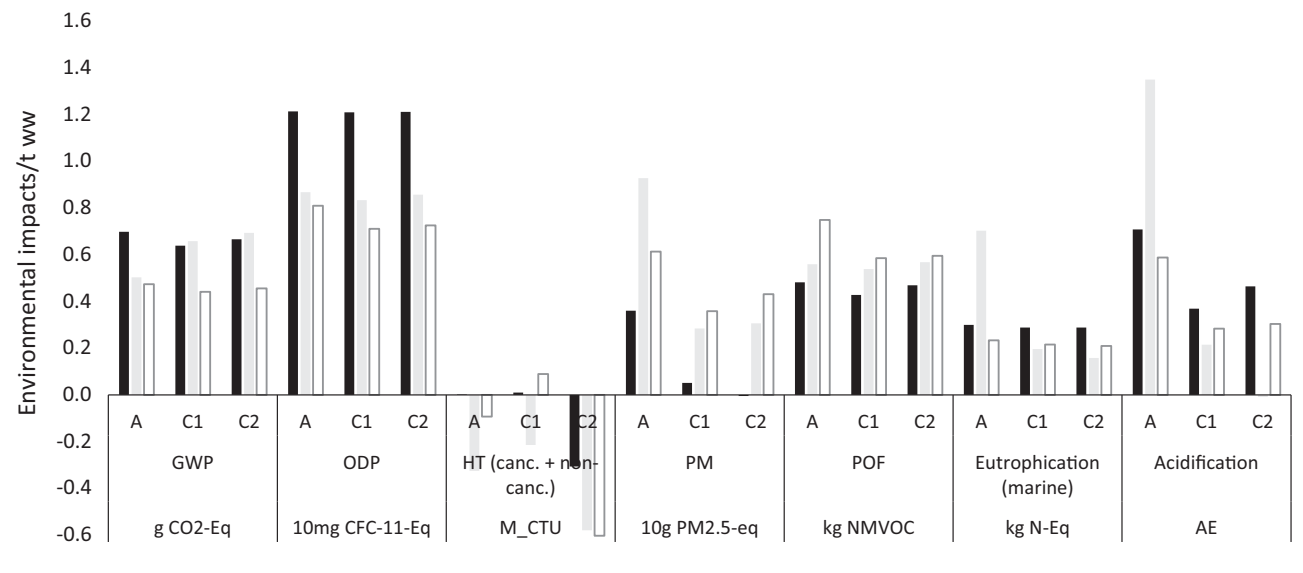

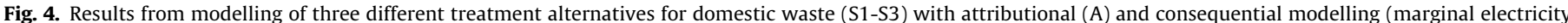

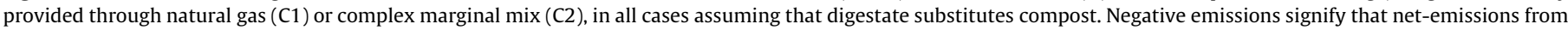
scenarios are negative.

the substitution of mineral fertilizers (Fig. 4). This is an effect of the relatively low net emission from the composting process as well as from the burning of waste in open air when compost is substituted.
ODP - Also here, landfill processes dominate emissions. Emissions are slightly higher in the attributional modelling, mainly due to a lower reduction of ODP per recovered unit of electricity 
generated in the different scenarios. Thus, reduction of ODP is higher in S2 and S3 where more electricity is recovered per ton waste.

HT - Substitution of the complex marginal energy results in large avoidance of toxic emissions, primarily as a result of the need for some of the elements used in construction/operation of solar, wind and nuclear power. Thus, with the C2 approach, S3 is more beneficial as this scenario results in the highest electricity recovery. Due to a much lower toxicity impact per kWh produced electricity with the $\mathrm{C} 1$ and attributional approach, substitution of fertilizers plays a more important role, making S3 the most beneficial alternative. The result is a change in the hierarchy between compared scenarios when comparing attributional and consequential modelling approaches.

PM - Substitution of marginal electricity result in larger reduction of PM compared to substitution of average electricity. As this is reflected also in provision of fertilizers, reduction of particulate matter is largest from S2. The result is a change in the hierarchy between compared scenarios when comparing the attributional and the two consequential modelling approaches.

POF - Emissions are primarily influenced by combustion of produced biogas and transports. Substitution of marginal electricity reduces impacts, but other processes are more relevant for overall results.

E - Eutrophication is to a large extent related to emissions from use of organic fertilizers (digestate) on farmland, and contribution is therefore higher from S2 (Fig. 3). However, when assuming that digestate substitutes composting, emissions resulting in eutrophication are avoided (Fig. 4). This is largely related to the avoided emissions of ammonia from the composting process. These are rather high, as an effect of assumedly high temperatures reached during the composting process, based on previously established correlation between temperature and ammonia emissions (BeckFriis et al., 2001). Thus, the modelling approach (attributional or consequential) can have a large impact on overall results in relation to this impact category, depending on the identification of affected processes.

A - Also acidification is strongly related to emissions from farmland as well as from composting. Thus, similarly to the case of eutrophication, the identification of affected processes in consequential modelling will determine to what extent the modelling approach is decisive to results within this impact category.

\subsection{Sensitivity analyses}

In order to investigate the impact of some of the many assumptions made in the consequential modelling of the processes substituted by goods provided by compared waste management alternatives, a number of sensitivity analyses were performed.
The differences in environmental impacts from production and use of urea and nitrate based fertilizers respectively can be vast (Harrison and Webb, 2001). Thus, in a second sensitivity analysis, calcium ammonia nitrate (CAN), was assumed to be the marginal nitrogen fertilizer. Global average data for provision of CAN was used in the modelling (Ecoinvent, 2013), containing, amongst others data for production of nitric acid. Production of nitric acid can lead to large emissions of greenhouse gases due to production of nitrous oxide as a waste product. Catalytic cleaning of nitrous oxide can however reduce nitrous oxide emissions by $70-90 \%$ (Jenssen and Kongshaug, 2003). This technology is currently introduced in production plants primarily in Northern Europe (Yara, 2015). Catalytic cleaning has also been introduced on Brazilian production plants (UNFCCC, 2006). The effects of such technology developments, resulting in a reduction of emissions of $\mathrm{N}_{2} \mathrm{O}$ in ammonia nitrate production by $80 \%$, were assessed. The choice of nitrogen fertilizer also affects emissions from on-land application of nitrogen fertilizers. Emission factors considered for estimating $\mathrm{NH}_{3}$ from urea and ammonium nitrates, as well as $\mathrm{CO}_{2}$ releases from urea application on farmland, were based on Hamelin et al. (2012). These adjustments would have an effect principally on the environmental impact categories climate change and eutrophication. As presented in Fig. 5, substitution of CAN would reduce contribution to GWP by $3-5 \%$ and contribution to eutrophication by $10 \%$ in $S 2$, when compared to the assumption that urea is the marginal fertilizer. On the other hand, technology development of nitric acid production, and thus reduced emissions of $\mathrm{N}_{2} \mathrm{O}$ from provision of CAN, would increase contribution to GWP by $2-4 \%$ compared to the base case, causing a change in the hierarchy between compared scenarios in relation to the impact category climate change.

In countries where domestic household waste is segregated at source for anaerobic digestion, nutrient recycling (with focus on phosphorus) is one of the main motivations (SEPA, 2016). As discussed above, the Brazilian consumption of phosphorus has increased vastly in later years, and further increase is expected (DNPM, 2014). According to the Brazilian National Department for Mineral Production (DNPM), the national reserves of $\mathrm{P}_{2} \mathrm{O}_{5}$ were estimated to 315 million tons in 2015, and several projects are currently under development to increase the Brazilian phosphorus production (DNPM, 2014). The cadmium content of phosphate rock varies vastly, between lower levels in igneous rocks (up to $0.25 \mathrm{mg}$ $\mathrm{Cd} / \mathrm{kg}$ rock) to higher levels in sedimentary rocks (up to $2.60 \mathrm{mg}$ $\mathrm{Cd} / \mathrm{kg}$ rock) (Smolder and Six, 2014). In later years, Brazil has reduced its import of highly cadmium containing sedimentary phosphorus fertilizers from countries such as Marrocos (DNPM, 2014). It could thereby be argued that recycled phosphorus in digestate in a Brazilian context will substitute fertilizers with a lower cadmium content compared to current global average. How-

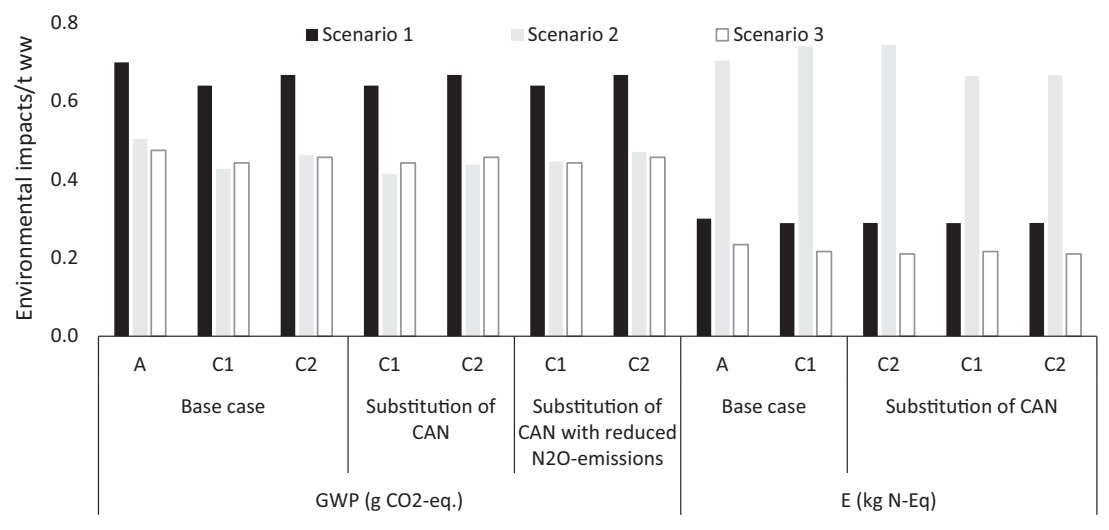

Fig. 5. Results from sensitivity analyses related to fertilizer substitution, change of assumed marginal mineral nitrogen fertilizer. 
ever, the global trend in phosphate fertilizers is rather an increase in cadmium content (Cichy et al., 2014). Thus, assuming that the mineral fertilizer market is global, it is more likely that digestate will substitute phosphorous fertilizers with higher cadmium content than current global average. The impact of a lower (a reduction of $90 \%$ was assumed, based on average difference in cadmium content between sedimentary and igneous phosphorus) as well as higher cadmium content (an increase by $20 \%$ was assumed) compared to the average was assessed in a sensitivity analyses. A reduced amount of cadmium in fertilizers could reduce avoidance of toxic emissions seen in S2 by 5-25\% (C2 and C1 respectively), while an increase by $20 \%$ would increase the avoidance of toxic emissions by $1-13 \%$ (C2 and $\mathrm{C} 1$ respectively) (Fig. 6). Neither the levels of increase nor decrease in the content of cadmium in fertilizers investigated in the sensitivity analyses would result in any changes of the hierarchy between investigated alternatives.

When assuming that the affected electricity is represented by the national energy plan (C2), variations of cadmium in fertilizers will have a low influence. This is explained by the use of cadmium in solar panels. As solar power will correspond to as much as $9.4 \%$ of overall changes in electricity production capacity until 2024, the commonly applied cadmium telluride (CdTe) technology, using water soluble and highly toxic cadmium chloride $\left(\mathrm{CdCl}_{2}\right)$, for production of solar panels will be dominant for the emissions related to human toxicity. However, use of magnesium chloride $\left(\mathrm{MgCl}_{2}\right)$ might substitute cadmium and thus vastly decrease toxicological impacts related to solar power (Major et al., 2014). The effect from such technological development was investigated, assuming that toxicological impacts would be reduced by $44 \%$ when $\mathrm{MgCl}_{2}$ substitutes CdTe (Werner et al., 2011). Results state that this would decrease avoidance of human toxicity impacts by between $3 \%$ and $6 \%$ from C2 scenarios (see SI for details).

No consideration was taken to potential sequestration of biogenic carbon in landfills and soils where digestate was used as fertilizer. In a sensitivity analysis, the influence of assuming the levels of carbon sequestration assumed by Smith et al. (2001) for European condition (presented in Section 2.3) was investigated. Results show that inclusion of carbon sequestration would reduce greenhouse gas emissions by between $2 \%$ and $5 \%$ (see SI for details). The influence from carbon sequestration is relatively seen small when compared to results presented by Smith et al. (2001) and Manfredi and Christensen (2009). This is mainly a result of emissions from landfills dominating the overall greenhouse gas emissions in the present study, due to a low landfill gas recovery ratio. The effects of a prolonged lifetime of landfills when food waste is segregated were not assessed in the base case of the present study. The landfill used as model in the present study has an

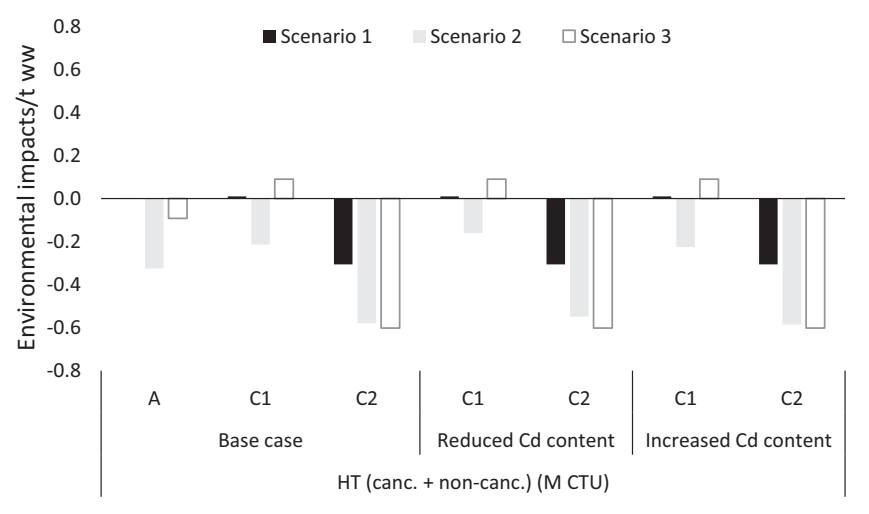

Fig. 6. Results from sensitivity analyses related to changes in cadmium (Cd) content in substituted phosphorus fertilizer. expected lifetime of 18 years (Abrelpe, 2012). Scenarios S2 and S3 would increase the lifetime by 4.2 and 5.4 years respectively. As the next landfill constructed in the Rio de Janeiro City area will be placed even further away from the city centre, one of the effects of the diversion organic waste is avoided emissions from transports of waste over a longer distance for several years. In order to quantify the environmental impacts of this, the future location of the next landfill to which waste would be transported is necessary. However, in a sensitivity analysis, it was assumed that the transport distance would increase by $50 \%$. The largest effect of such a change is related to emissions of particulate matter, increasing by 85 and $102 \%$ in C1 and C2 modelling respectively in case of no diversion of food waste (S1), while emissions would increase by less than $20 \%$ in S3 with the largest diversion of food waste from landfills (see SI for details).

\section{Discussion}

Results from the case study show that a change from the current waste management strategy, focused on sanitary landfills, to post-separation of organic fraction food waste could decrease GHG-emissions from waste management by more than 30\% when applying an attributional modelling. However, with a consequential modelling, assuming substitution of electricity generated from natural gas and marginal mineral fertilizers through sourcesegregation of organic waste, this strategy appears more beneficial in relation to GHG-emissions. Thus, results suggest that the chosen methodological approach could have a large effect on the relative performance of compared treatment alternatives. This differs from previous conclusions presented by Sandin et al. (2014), stating that the choice of methodological approach does not seem to influence the relative performance of different end-of-life treatment alternatives. However, large differences in absolute emissions from the two modelling approaches were identified by the same authors, as well as in the present study.

The two approaches used for identification of marginal electricity would in both cases increase emissions related to all assessed environmental impact categories, except human toxicity, when compared to average data used in attributional modelling. As more electricity is produced than consumed in all compared scenarios, consequential modelling will in most cases results in higher avoidance of environmental impacts, compared to attributional. This is to some extent counter-acted by electricity used in the waste treatment process. Thus, the differences between the compared approaches might appear smaller than expected.

Findings in the present paper partly follows the ones presented by Lund et al. (2011), showing that a complex marginal electricity mix renders lower environmental impacts compared to the commonly used assumption of natural gas being the marginal fuel for electricity provision. However, as the present study is not limited merely to an assessment of GHG-emissions, it shows that a complex marginal electricity mix can generate higher impacts than the single marginal technology in relation to other impact categories. The chosen approach used for identification of marginal electricity would, however, in the present study, change the hierarchy between compared waste management scenarios in relation to only one or two of the assessed impact categories, depending on the processes assumedly substituted by produced digestate.

Similar to the approach chosen by Boesch et al. (2014) and Sevigné-Itoiz et al. (2015), the present paper uses governmental long-term planning documents as basis for the identified marginal electricity mix. The many uncertainties connected to long-term energy plans will surely reduce the predictability in this type of documents. As shown by Mathiesen et al. (2009), such plans are seldom fully realized, for several different reasons. Thus, as pro- 
posed by Mathiesen et al. (2009), it could be interesting to create alternative projections, adjusted for some key assumptions, such as high or low oil prices, and political will for investments in nuclear energy.

Different from several other LCAs of waste management alternatives, the present study provides an attempt to identify marginal technologies not only for energy provision, but also for provision of materials substituted by goods from the waste management process. The assumption of the product substituted by digestate being compost or mineral fertilizers will have a large influence on the impact categories climate change and eutrophication. This shows the importance of identifying affected suppliers also of products recovered from waste management systems, in order to generate relevant outcomes for decision support, although this not always is seen in previous consequential LCAs of waste management systems (Tonini and Astrup, 2012; Boesch et al., 2014; Sevigné-Itoiz et al., 2015). Different from studies presented by Cimpan et al. (2015), the present study does not account for cascading effects, i.e. release of capacity in landfills when organic waste is treated through anaerobic digestion. Villanueva and Wenzel (2007) stated that alternative use of treatment capacity should be included in LCA of material recycling, but that the consequence in the long term is not avoided treatment through capacity release, but avoided construction of new capacity, as the market will adjust for a trend towards an increased material recovery. This was in the present study investigated in a sensitivity analysis, demonstrating that prolonged lifetime could result in vast benefits, primarily in relation to emissions of particulate matter through reduced risks of increasing transport distance. Including other cascading effects (for example assuming that released capacity in landfills would avoided use of uncontrolled dumpsites), can certainly increase even further the difference between results and conclusions between attributional and consequential modelling of different waste management alternatives.

As stated by Ekvall and Weidema (2004), it is not reasonable to assume that the environmental properties of the technologies in the future are accurately described with data used in attributional modelling, as these represent current or even historical technologies. However, it can also be risky to consider future technological advances in environmental assessments of future systems. Scenario modelling, applying dynamic modelling, describing expected and surprise-free future scenarios has been suggested for investigation of probable technological developments (Ekvall and Weidema, 2004). This was in the present paper represented by exploring the effects of a change from cadmium telluride to magnesium chloride in solar power cells as well as by large scale use of catalytic reduction of nitrous oxide emissions from production of nitrous fertilizers. Result from these sensitivity analyses state that the assumed technology level can be of vast importance to overall environmental impacts from investigated treatment alternatives.

In summary, the present study shows that not only the chosen modelling approach (attributional or consequential), but also the identification of marginal processes can affect both absolute impacts and ranking of compared waste management scenarios. As pointed out by Ekvall and Weidema (2004), the future is inherently uncertain. The actual future processes substituted by the goods generated in the different waste management treatment alternatives are defined by factors that we cannot predict at present, such as future prices of chemical fertilizers and fuels, as well as political decisions on taxes etc. This could be interpreted as if LCA results generated with consequential modelling are associated with larger uncertainties than results generated with attributional modelling (Schmidt and Weidema, 2009). It should, however, be remembered that although there may be large uncertainties concerning what and how unit processes are affected by a change in the studied system, the answer cannot be to opt for an alternative that certainly is not accurate, reflecting the past rather than the future. In countries like Brazil, electricity provision has historically been dominated by technologies that present rather low environmental impacts. However, as projections point at an increased use of electricity generation with larger environmental impacts, attributional modelling could result in a risk of underestimating potential benefits from efficient energy and material recovery of waste.

\section{Conclusions}

The present case study has shown that the chosen approach certainly can have an effect on conclusions drawn from LCAs of solid waste management systems. In cases where waste management results in substitution of electricity and materials through energy recovery and recycling, environmental benefits increases with an increased environmental burden from the products assumedly substituted. Thus, if the processes identified as affected by changes in the waste management system have a higher environmental impact than the average, it is likely that waste treatment alternatives including efficient energy and material recovery will come across as more beneficial when consequential modelling is applied - and the other way around. Thus, when compared to attributional modelling, application of a consequential modelling could both increase as well as decrease the environmental benefits from the different waste management alternatives compared in the present study, depending on the processes included in the consequential modelling. The many uncertainties related to identification of processes affected by the changes investigated in the specific LCA should not limit the use of a consequential modelling. Rather, systematic investigation of alternative processes can present the range in which results are most likely to be found, and the most relevant factors for different outcomes can be identified. The present study clearly shows that different approaches in identifying affected processes can affect overall results vastly. In order to facilitate the interpretation of gained results, a multi-criteria analysis could be performed, using relevant methods for weighting of different environmental impact categories. This will be developed in a second phase of the present project.

\section{Appendix A. Supplementary material}

Supplementary data associated with this article can be found, in the online version, at http://dx.doi.org/10.1016/j.wasman.2017.07. 002 .

\section{References}

ANDA, 2015. ASSOCIAÇ̃̃O NACIONAL PARA DIFUSÃO DE ADUBOS - ANDA. Mercado de fertilizantes: janeiro-maio/2015, São Paulo. http://www.anda.org.br/ estatistica/comentarios.pdf.

Andersen, J.K., Boldrin, A., Christensen, T.H., Scheutz, C., 2011. Mass balances and life cycle inventory of home composting of organic waste. Waste Manage. 31 (9-10), 1934-1942.

ANEEL, 2009. Agência Nacional de Energia Elétrica. Atlas de Energia Elétrica do Brasil, parte 3: Carvão. http://www2.aneel.gov.br/arquivos/pdf/ atlas_par3_cap9.pdf.

Angelo, A.C.M., Bernstad Saraiva, A., Clímaco, J.C.N., Infante, E., Valle, R., 2017. Life Assessment and Multi-criteria Decision Analysis: Selection of a strategy for domestic food waste management in Rio de Janeiro. J. Cleaner Prod. 143, 744756.

ANP, 2015. Agência Nacional Do Petróleo. Gás Natural e Biocombustíveis, Produção Nacional de Derivados de Petróleo (metros cúbicos). http://www.anp.gov.br/? $\mathrm{pg}=18599 \& \mathrm{~m}=\& \mathrm{t} 1=\& \mathrm{t} 2=\& \mathrm{t} 3=\& \mathrm{t} 4=\& \mathrm{ar}=\& \mathrm{ps}=\& 1449492438759$

Abrelpe, 2012. Atlas Brasileiro de Emissões de GEE e Potencial Energético na Destinação de Resíduos Sólidos. http://www.abrelpe.org.br/arquivos/ atlas_portugues_2013.pdf.

Aprelpe, 2014. Panorama dos resíduos sólidos no Brasil 2013, Abrelpe, São Paulo, Brazil. http://www.abrelpe.org.br/Panorama/panorama2013.pdf. 
Balmér, P., 2012. Strategies for use of sludge (Strategier för slamanvändning, in Swedish). VA-strategi AB. Presentation, VA-mässan, September 2012.

Beck-Friis, B., Smars, S., Jonsson, H., Kirchmann, H., 2001. Gaseous emissions of carbon dioxide, ammonia and nitrous oxide from organic household waste in a compost reactor under different temperature regimes. J. Agric. Eng. Res. 78, 423-430.

Bernstad, S.S.A., Andersson, T., 2015. Food waste minimization from a life-cycle perspective. J. Environ. Manage. 147, 219-226.

Boesch, M.E., Vadenbo, C., Saner, D., Huter, C., Hellweg, S., 2014. An LCA model for waste incineration enhanced with new technologies for metal recovery and application to the case of Switzerland. Waste Management (New York, N.Y.), 34 (2), 378-89. doi: http://dx.doi.org/10.1016/j.wasman.2013.10.019.

Borgshed, J., Leander, J., Rönnquist, E.-M., Steinwall, P., 2003. Systems Analysis of Waste Treatment in the Kalmar Region. Carl Bro Energy Consultancy (in Swedish), Kalmar, Sweden.

Cichy, B., Jaroszek, H., Paszek, A., Tarnowska, A., 2014. Cadmium in phosphate fertilizers; ecological and economical aspects. In: Proceedings from XV Conference Environmental, vol. 10, pp. 837-842. http:// www.chemikinternational.com/wp-content/uploads/2014/10/3.pdf.

Cimpan, C., Rothmann, M., Hamelin, L., Wenzel, H., 2015. Towards increased recycling of household waste: Documenting cascading effects and material efficiency of commingled recyclables and biowaste collection. J. Environ. Manage. 157, 69-83.

COMLURB, 2014. Caracterizações gravimétrica e bacteriológica de resíduos sólidos domiciliares. Cidade do Rio de Janeiro - 2013.

Curran, M.A., Mann, M., Norris, G., 2005. The international workshop on electricity data for life cycle inventories. J. Cleaner Prod. 13 (8), 853-862.

Da Silva, G.F., 2011. Aterro sanitário São João: estudo dos indicadores ambientais em emergia. Universidade Paulista - UNIP, Brazil. Master Thesis.

DNPM, 2014. Brazilian National Department for Mineral Productio (Departamento Nacional da Produção Mineral). Fosfato - Sumário Mineral 2014. http://www. dnpm.gov.br/dnpm/sumarios/fosfato-sumario-mineral-2014/view.

DWMT, 2014. Database of Waste Management Technologies AD 2: Dry AD followed by covered windrows composting. <http://www.epem.gr/waste-ccontrol/database/html/AD-01.htm>.

EC, 2010. International reference life cycle data system handbook. General guide for Life Cycle Assessment - Detailed Guidance. Joint Research Centre Institute for Environment and Sustainability, European Commission, Ispra, Italy.

Ecoinvent 3.0. LCI Database, Ecoinvent Center, 2013. Swiss Center for Life Cycle Inventory. http://www.ecoinvent.org/database/.

Ekvall, T., Weidema, B., 2004. System boundaries and input data in consequential life cycle inventory analysis. Int. J. LCA 9 (3), 161-171.

EPA, 2015. Advancing Sustainable Materials Management: 2013 Fact Sheet, EPA Washington, US. http://www.epa.gov/wastes/nonhaz/municipal/pubs/2013 advncng_smm_fs.pdf.

EPE, 2015. Empresa de Pesquisa de Energia. Results from Auctions FA 2015, A-5 2015, A-1 Reserva 2015 and A-3 2015. http://www.epe.gov.br/PDEE/Relat\%C3\% B3rio\%20Final\%20do\%20PDE\%202024.pdf.

EPE/MME, 2014. Plano Decenal de Expansão de Energia 2024. Empresa de Pesquisa Energética - EPE/Ministério de Minas e Energía, Brasilia, Brazil.

FAO, 2002. Fertilizer use by crop in Brazil. Chapter 4. The fertilizer sector. http:// www.fao.org/3/a-y5376e/y5376e08.htm.

Finnveden, G., Johansson, J., Lind, P., Moberg, Å., 2000. Life Cycle Assessments of Energy from Solid Waste. FMS Report 137.

Genrup, M., Jonshagen, K., 2011. Integration of bio-fired gas turbines in combined heat and power generation. Värmeforsk Report 1164. Stockholm, Sweden.

Hamelin, L., Jørgensen, U., Petersen, B.M., Olesen, J.E., Wenzel, H., 2012. Modelling the carbon and nitrogen balances of direct land use changes from energy crops in Denmark; a consequential life cycle inventory. Global Change Biol. Bioenergy 4, 889-907.

Hamelin, L., 2013. Carbon management and environmental consequences of agricultural biomass in a Danish Renewable Energy strategy. PhD Thesis, Department of Chemical Engineering, Biotechnology and Environmental Technology. University of Southern Denmark (Faculty of Engineering).

Harrison, R., Webb, J., 2001. A review of the effect of $\mathrm{N}$ fertilizer type on gaseous emissions. Adv. Agron. 71, 65-108.

IBGE, 2013. IBGE, Diretoria de Pesquisas, Coordenação de Agropecuária, Produção Agrícola Municipal 2013. Rio de Janeiro.

ILCD, 2011. Recommendations for Life Cycle Impact Assessment in the European Context. European Commission Joint Research Centre, Institute for Environment and Sustainability, Ispra, Italy.

IPCC, 2006. N2O emissions from managed soil as and CO2 emissions from lime and urea application. Guidelines for National Greenhouse Gas Inventories, vol. 4, Chapter 11, Agriculture, Forestry and Other Land Use.

IPEA, 2014. PNRS Observatory: solid waste final destination. Institute for Applied Economic Research. Brasília, DF, Brazil. <http://observatoriopnrs.org/ destinacao-final/> (Accessed 07.04.15).

Jenssen, T.K., Kongshaug, G., 2003. Energy consumption and greenhouse gas emissions in fertiliser production. In: Proceedings No. 509. The International Fertiliser Society, London, UK.

Laurent, A., Clavreul, J., Bernstad, A., Bakas, I., Niero, M., Gentil, E., Christensen, T.H., Hauschild, M.Z., 2013. Review of LCA studies of solid waste management systems - Part I: Key learnings and perspectives. Waste Manage. 34, 573-588.

Lund, H., Mathiesen, N., Christensen, P., Schmidt, J.H., 2011. Energy system analysis of marginal electricity supply in consequential LCA. Int. J. Life Cycle Assess. 15, 260-271. http://dx.doi.org/10.1007/s11367-010-0164-7.
Major, J.D., Treharne, R.E., Phillips, L.J., Durose, K., 2014. A low-cost non-toxic postgrowth activation step for CdTe solar cells. Nature. http://dx.doi.org 10.1038 /nature13435.

Manfredi, S., Christensen, T.H., 2009. Environmental assessment of solid waste landfilling technologies by means of LCA-modeling. Waste Manage. 29, 32-43.

Mathiesen, B.V., Münster, M., Fruergaard, T., 2009. Uncertainties related to the identification of the marginal energy technology in consequential life cycle assessments. J. Cleaner Prod. 17 (15), 1331-1338. http://dx.doi.org/10.1016/j. jclepro.2009.04.009.

MME, 2015. Ministério de Minas e Energia. Balanço Energético Nacional 2015. http://www.mme.gov.br/web/guest/publicacoes-e-indicadores/balancoenergetico-nacional.

Nordic Council of Minister, 2007. Biowaste - decision support tool for collection and treatment of source-sorted organic municipal solid waste. TemaNord 2007, 602 http://norden.diva-portal.org/smash/get/diva2:701837/FULLTEXT01.pdf.

ONS, 2015. Operador Nacionál do Sistema elétrico. PAR - Plano de Ampliação e Reforços.

OSB/WSTB, 2000. Ocean Studies Board and Water Science and Technology Board.

PDE, 2014. Plano Decenal de Energia. EPE, Rio de Janeiro, Brasil.

PNE, 2014. Plano Nacional De Energia (PNE) 2050. Empresa de Pesquisa Energética, Rio de Janeiro, Brazil.

Portal Brasil, 2014. Petrobras firma acordo para importação de gás natural boliviano. Published in August 2014. (Accessed 20151020).

Riber, C., Pedersen, C., Christiansen, T.H., 2009. Chemical composition of material fractions in Danish household waste. Waste Manage. 29 (4), 1251-1257.

Sandin, G., Peters, G.M., Svanström, M., 2014. Life cycle assessment of construction materials: the influence of assumptions in end-of-life modelling. Int. J. Life Cycle Assess. 2014 (19), 723-731.

Schmidt, J.H., Weidema, B., 2009. Response to the public consultation on a set of guidance documents of the International Reference Life Cycle Data System (ILCD) Handbook. 2.-0 LCA Consultants.

SEPA, 2016. Increased recycling of food waste. http://www.naturvardsverket.se Miljoarbete-i-samhallet/Miljoarbete-i-Sverige/Uppdelat-efter-omrade/Avfall/ Atervinning-av-matavfall/.

Sevigné-Itoiz, E., Gasol, C.M., Rieradevall, J., Gabarrell, 2015. Contribution of plastic waste recovery to greenhouse gas (GHG) savings in Spain. Waste Manage. 46, 557-567.

Shen, Y., Ren, L., Li, G., Chen, T., Guo, R., 2011. Influence of aeration on CH4, N2O and NH3 emissions during aerobic composting of a chicken manure and high $\mathrm{C} / \mathrm{N}$ waste mixture. Waste Manage. 31, 33-38.

Six, L., Smolders, E., 2014. Future trends in soil cadmium concentration under current cadmium fluxes to European agricultural soils. Sci. Total Environ. 2014 Jul 1, 485-486, 319-28.

Smith, A., Brown, K., Ogilvie, S., Rushton, K., Bates, J., 2001. Waste management options and climate change: final report. European Commission, DG Environment. http://ec.europa.eu/environment/waste/studies/pdf/climate change.pdf.

Sonnemann, G., Vigon, B., 2011. Global guidance principles for life cycle assessment databases - a basis for greener processes and products, UNEP/SETAC. http:// www.unep.fr/shared/publications/pdf/DTIx1410xPAGlobalGuidancePrinciplesforLCA.pdf.

Tonini, D., Astrup, T., 2012. Life-cycle assessment of a waste refinery process for enzymatic treatment of municipal solid waste. Waste Manage. 32 (1), 165-176.

UNFCCC, 2006. PROJECT DESIGN DOCUMENT FORM (CDM PDD). N2O Emission Reduction in nitric acid plant Paulínia, SP, Brazil. https://cdm.unfccc. int/filestorage/8/A/5/8A5I01X4L4L6W920QGQZFOF8B0VOBW/Brazil\%20PDD. pdf?t=aFp8bnlmOWtjfDCL1lCPmoLyHTKoDgCpDbqo.

Vázquez-Rowe, I., Rege, S., Marvuglia, A., Thénie, J., Haurie, A., Benetto, E., 2013. Application of three independent consequential LCA approaches to the agricultural sector in Luxembourg. Int. J. Life Cycle Assess. 18 (8), 1593-1604 http://dx.doi.org/10.1007/s11367-013-0604-210.1038/nature11811.

Waste Management Sweden, 2013. Pretreatment of food waste for biogas production (in Swedish: Förbehandling av matavfall för biogasproduktion). Report B2013:01. ISSN 1103-4092. Waste Management Sweden, Malmö, Sweden.

Waste Sweden, 2014. Avfallsstatistik. Avfall Sverige, Malmö, Sweden. http://www avfallsverige.se/statistik-index/avfallsstatistik/.

Weidema, B.P., Ekvall, T., Heijungs, R., 2009. Guidelines for application of deepened and broadened LCA. Final report Co-ordination Action for innovation in LifeCycle Analysis for Sustainability - Calcas. Project no.037075.

Werner, J.J., Zapf-Gottwick, R., Koch, M., Fischer, K., 2011. Toxic substances in photovoltaic modules. In: The 21st International Photovoltaic Science and Engineering Conference November 28th - December 2nd, 2011, Fukuoka, Japan.

Villanueva, A., Wenzel, H., 2007. Paper waste - recycling, incineration or landfilling? A review of existing life cycle assessments. Waste Manage. (Oxford) 27, S29S46.

Yara, 2015. Garanti klimatavtryck. http://www.yara.se/images/YARA GarantiKlimatavtryck_Sv_2014_tcm422-106645.pdf.

Yokelson, R.J., Christian, T.J., Karl, T.G., Guenther, A., 2008. The tropical forest and fire emissions experiment: laboratory fire measurements and synthesis of campaign data. Atmos. Chem. Phys. 8, 3509-3527.

Yoshida, H., Monster, J., Scheutz, C., 2014. Plant-integrated measurement of greenhouse gas emissions from a municipal wastewater treatment plant Water Res. 61, 108-118. 